\title{
The Significance of Economic Trade Relation for Regional Integration in the West Balkans'
}

\author{
Engjëll Pere ${ }^{A}$ \\ Received: May 2009 | Revised: October 2009 | Accepted: October 2009
}

\begin{abstract}
Integration of Balkans countries in European Union is proceeding in two main pillars, which are developed in parallel:

Integration, as an internal process for these countries, building up of a market economy and of a democratic society. It is seen as a wide and a long-term process. It is related with implementation of broad reforms in view of political system, market economy, and social society. It is concretized in the setting up and development of politic and market institutions.

Integration as a process of regional cooperation. This process includes a broader different dimension of political, cultural, social, and economical aspects. Between these, a economic relations are of particular importance, which are also reflected in the liberalization of economic relations and creation of free economic zone in the region.

In this point of view European integration of West Balkans countries has two main dimensions: (i) bilateral relations of European Union (EU) and (ii) their regional integration. from this point of view, economic relations have a particular importance. This paper intends to give a comparative analyze of trade relations between West Balkans countries. It provides the progress of foreign trade integration policies in West Balkan region, focusing on some particular moments, from Free Trade Agreements up to CEFTA -2006. Furthermore, it reflects general aspects of economic opening of West Balkan countries, macroeconomic developments, progress of exports and imports, trade balances, the trends of regional integration against the European Union, etc. In the paper are analyzed economic trade relation between Albania, Bosnia-Herzegovina, Croatia, Macedonia (UN recognized as FYROM), Montenegro, and Serbia.
\end{abstract}

Key Words: Integration; foreign trade relation; West Balkan.

\section{Economic trade relation in focus of regional integration of West Balkans Countries}

West Balkans Countries where are included Albania, Bosnia-Herzegovina, Croatia, Macedonia ${ }^{1}$, Montenegro and Serbia, have make clear their politic orientation, that of integration to the European Union.

A characteristic aspect of this integration is the cooperation and regional integration of these countries, as a first step in their European integration. In the political-economic literature it has been noticed even the idea of the integration of these West Balkans Countries in block, of course considering the specific countries reforms development.

In the politic aspect, regional cooperation and collaboration of the West Balkan countries is considered of particular importance in the political stability and safety, not only for the region in general but even for individual countries. In the view of economic development, the economic integration of these countries is considered of the same importance. The importance of regional integration in general and economic in particular are mostly related to these main aspects: (i) already exists an EU bloc integration experience of the new candidates countries entering in bloc, experience that likely seems to continue; (ii)regional integration is considered as a preliminary phase and as a "school" for passing to a higher step of the integration as it is the EU; (iii) the fact that economic blocs have advantage compared to the development of special economies with low cooperation level is well known; (iv) for the West Balkan Countries, since we are talk about small economies and with a low level of development, is necessary that they act through different forms of regional collaboration.

1 UN recognized as FYROM. 


\section{The progress of regional integration policies in the West Balkan Countries}

The first moment toward the lay of new political-economical cooperation basis among West Balkan Countries was the South-East Stabilization Pact, signed on 1999 (10 June 1999, Köln- FR of Germany). In fact one of the main reasons for undertaking this pact was the dramatic occurrence of the Kosovo war. In this aspect one the primary objectives of the Stabilization Pact was the stabilization of political-economical situation in Kosovo. However, keeping prezent the regional situation, the Pact aimed to establish a stabilization and cooperation betwen the countries in the region (Albania, Croatia, Montenegro, Serbia, Bosnia Herzegovina, Macedonia, Bulgaria, Rumania and Moldavia) ${ }^{2}$. The Stabilization Pact consisted of three main problems blocks: first democratization and human rights; second, reconstruction, development and economic collaboration and third, the block of safety issues.

In the group of economic problems group, starting from the fact that the West South European countries were small and relatively underdeveloped economies, the main development possibilities were specified those of the trade, transport and energy. In fact, in these fields these economies cannot have other development alternatives, except their regional collaboration and cooperation ${ }^{3}$.

Starting from this background we will focus mainly in economic-commercial relations through West Balkan Countries. The development of trade relations among countries, first of all presuppose their liberalization. In this aspect a particular importance will have the signing of Free Trade Agreement (FTA)between different countries
A characteristic of these agreements is that they were bilateral and not a single one for the entire region. Such thing has created many problems for their expansion in the entire region, bringing many difficulties for the establishment of a single free trade zone through the so called "scale economy". For this reason, with the incentive and support of the international community, the countries agreed the implementation of a necessary minimum level of standards in their free trade agreements. This was concretized on June $27^{\text {th }}, 2001$ through the "Memorandum of Understanding on Trade Liberalization and Facilitation -MoU". Some of the main standards were: (i) elimination of any new restrictive measure in the field of trade and establishment of limits and defined unique basic rules (WTO/EU); (ii) elimination of import tax for at least $90 \%$ of the Harmonized tariffs System and the reduction of the tariffs for sensitive products (within 6 years); (iii) facilitation and harmonization of custom procedures, service liberalization etc.

The next important step was the inclusion of West Balkan countries in CEFTA 2006 (Central European Free Trade Agreement). CEFTA 2006 is a free trade agreement between West Balkan Countries plus Moldavia that is based on bilateral agreements among these countries. Initially in CEFTA 2006 agreement were included Poland, Hungarian, Czech Republic and Slovakia (21 December 1992, Krakow - Poland), later Slovenia (1996), Rumania (1997), Bulgaria (1999). The main aim of this agreement was to encourage member countries toward EU approximation and integration. Part of it could become countries that fulfilled three main conditions: (a) were member of the WTO (b) had signed an EU

Table 1. Matrix of Free Trade Agreements in West Balkan Region

\begin{tabular}{|l|c|c|c|c|c|}
\hline & Albania & Macedonia & Serbia \& Montenegro & Bosnia \& Herzegovina & Croatia \\
\hline Albania & & SEE-FTA 2002 & SEE-FTA 2004 & SEE-FTA 2004 & SEE-FTA 2003 \\
\hline Macedonia & & SEE-FTA 2006 & SEE-FTA 2002 & SEE-FTA 2002 \\
\hline Serbia \& Montenegro & & & & SEE-FTA 2002 & SEE-FTA 2004 \\
\hline Bosnia \& Herzegovina & & & & & SEE-FTA 2005 \\
\hline Croatia & & & & \\
\hline
\end{tabular}

of the region. Such agreements are based in the reduction of the tariffs (up to their elimination), quotes and preferential politics for the products. They are considered as the second phase of the regional integration of the countries. ${ }^{4}$ Since the beginning of 2006, all West Balkan Countries have finished free trade agreement matrices between each other. Albania is considered a country that has fulfilled relatively quickly the frame of FTA with other West Balkans countries, undersigning FTA with Macedonia in 2002; with Croatia 2003; with Serbia and Montenegro and Bosnia \& Herzegovina 2004. The table 1 presents the matrix of free trade agreement signatures for West Balkan Countries:

2 On 28 February 2008 the Stabilization Pact had to be substituted by the Regional Cooperation Council - RCC consisting of the region member them self, but always in the international community support and monition.

3 European Commission - Regional cooperation in the western Balkans; A policy priority for the European Union (2005)

4 Economic Integration can be classified in 6 main steps: preferential trade, free trade agreement, customs union, common market, economic and monetary union, entire economic integration. association agreement (c) had signed a free trade agreement with the member countries.

By the full EU membership of many of these countries, on April 2006 (Bucharest-Rumania) started the initiative for enlargement of CEFTA with new members like Albania, Bosnia-Herzegovina, Montenegro, Serbia and Moldavia. This agreement was signed on December 2006 (19 December 2006, Bucharest-Rumania) and entered into force on November 2007. Its main goal was the establishment of the free trade zone between member countries starting from $31 \mathrm{De}$ cember 2010. So it is foreseen to have full liberalization of the import tariffs for industrial products and a special liberalization for agriculture goods (starting from "sensitiveness" of these goods in the trade structure of each country).

\section{Macroeconomic development of the West Balkan Countries}

Before we analyze the economic relations among different West Balkan countries, it is necessary to have an overall view of macroeconomic development of these countries. 
Table 2. Main macroeconomics figures of West Balkans Countries

\begin{tabular}{|c|c|c|c|c|c|c|c|c|c|c|}
\hline & \multicolumn{2}{|c|}{ GDP Growth (\%) } & \multicolumn{2}{|c|}{$\begin{array}{l}\text { GDP Inflation } \\
\text { Deflator (\%) }\end{array}$} & \multicolumn{2}{|c|}{$\begin{array}{l}\text { GNI per Capita } \\
\text { (USD-Atlas method) }\end{array}$} & \multicolumn{2}{|c|}{$\begin{array}{l}\text { Open Index (Merchandise } \\
\text { trade } \% \text { of GDP) }\end{array}$} & \multicolumn{2}{|c|}{$\begin{array}{c}\text { Foreign direct } \\
\text { investment (\% of GDP) }\end{array}$} \\
\hline & 2005 & 2006 & 2005 & 2006 & 2005 & 2006 & 2005 & 2006 & 2005 & 2006 \\
\hline Albania & 5.5 & 5.0 & 3.5 & 2.0 & 2,170 & 2,930 & 39 & 42 & 3.1 & 3.6 \\
\hline Macedonia & 4.1 & 3.0 & 3.8 & 2.7 & 2,840 & 3,070 & 91 & 99 & 1.7 & 5.6 \\
\hline Serbia & 6.2 & 5.7 & 15.1 & 15.6 & 3,570 & 4,030 & 59 & 61 & 5.6 & 16.0 \\
\hline Montenegro & 4.3 & 16.2 & 3.5 & 2.6 & 3,270 & 4,130 & 86 & 97 & - & - \\
\hline $\begin{array}{l}\text { Bosnia \& } \\
\text { Herzegovina }\end{array}$ & 5.0 & 6.0 & 2.1 & 6.5 & 2,890 & 3,230 & 88 & 87 & 4.8 & 3.5 \\
\hline Croatia & 4.3 & 4.8 & 3.2 & 3.4 & 8,360 & 9,310 & 70 & 74 & 4.6 & 7.9 \\
\hline Euro zone & 1.5 & 2.7 & 2.2 & 2.3 & 32,332 & 34,307 & 61 & 65 & 3.4 & 3.8 \\
\hline
\end{tabular}

Source: World Bank; (World Development Indicators 2008)

After the '9o all West Balkan countries passed in a relatively long transition period, not only of their socio-economic systems, passing from a centralized economy to a free trade one, but many of them faced dramatic conflicts, as the wars in ex Yugoslavia. From many years West Balkan was identified with the notions of the ethnic conflicts, negation of minority rights, massive and uncontrolled emigration, civil wars among different nationalities etc. Such situation, of course, has influenced in their overall economic development, and especially relations between them.

However, passing to a democratic system sustaining in the free market mechanisms, and relations with west countries, today, after 15-17 years, have brought a certain level of development and macroeconomic stabilization. Table 2 shows some of the macroeconomic figures of the West Balkan countries for the years 2005-2006.

From these figures it is evidenced the fact that West Balkan countries are of a low income level per capita (GNIGross National Income per Capital). The indexes are far away from the average of Euro zone. Croatia has the highest level (classified in the group with highest income level per capita). It is clear an increase of incomes from 2005-2006. Regarding inflation, beside Serbia, all data show stability. The same can be said on growth rate that were twice higher compared to Euro zone.

Regarding, the Foreign Direct Investment, the best figures are those of Serbia, Croatia and Macedonia, BosniaHerzegovina and Albania. However, according to the scale of opening of the economy ${ }^{5}$, it noticed the increase of this index, that shows the increase in the integration scale, but also we see that this index has relatively lower levels for Albania. Between these indexes, the foreign direct investment on one side, and the scale of opening of the economy on the other, I think that there is an important relation and correlation. The goal to increase economic collaboration and integration in general, and in regional level in particular, should be considered as a resulting objective of a direct economic correlation between foreign trades with whole economic development. In fact the increase of foreign trade level, exports in particular, means increase of competitiveness for the entire economy, thus producing with relatively lower cost, higher quality etc. On the other side, these com-

\footnotetext{
5 Calculated as a ratio of total export and import to GDP.
}

petitiveness can be achieved only through new technologies, which necessarily need foreign investment. There for, beside other factors, the relatively low level of opening of the economies of Albania is related with the relatively low level of foreign direct investment in these countries.

However, all the countries are characterized by a gradual but stable increase of the scale of economic opening. Characteristic is the fact that they present a considerable deficit in foreign relations. In the following graphs is presented the ratio of current account deficit for each country for the period $2000-2006$ (Figure 1).

More negatively is the situation of trade deficits that is shown by the covering level of imports with exports by the countries (calculated as the percentage of exports to total imports). This index for 2007 is presented as:

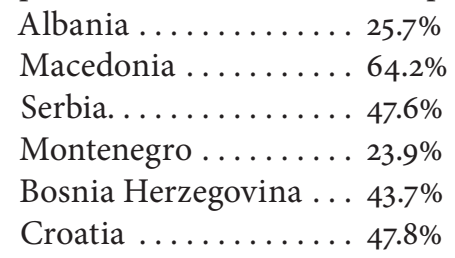

As we see the coverage coefficient is lower for Montenegro and Albania, even though Kosovo has a low one, it has increased from $4.9 \%$ in 2005 to $8.6 \%$ in 2006 and $10.5 \%$ in 2007.

\section{Trade relationships between West Balkan Countries}

The economic agreements in the free trade area signed among West Balkan member countries, theoretically in the literature are based in the idea of the advantages represented by the establishment of the economic blocs or the monetary unions. Especially in the condition of West Balkan countries, with small economies where the establishment of free trade zones will create opportunities and bring benefits from economies of scale.

Yet, many studies have shown that practically the role of free trade agreements was not able to develop in a visible way the economic relations between these countries. Export and import data for 2007 between these countries are presented in Table 3 and Table 4 . In these tables are presented the percentage of import and export for particular countries in the region, versus the total import and export for each respective country. 

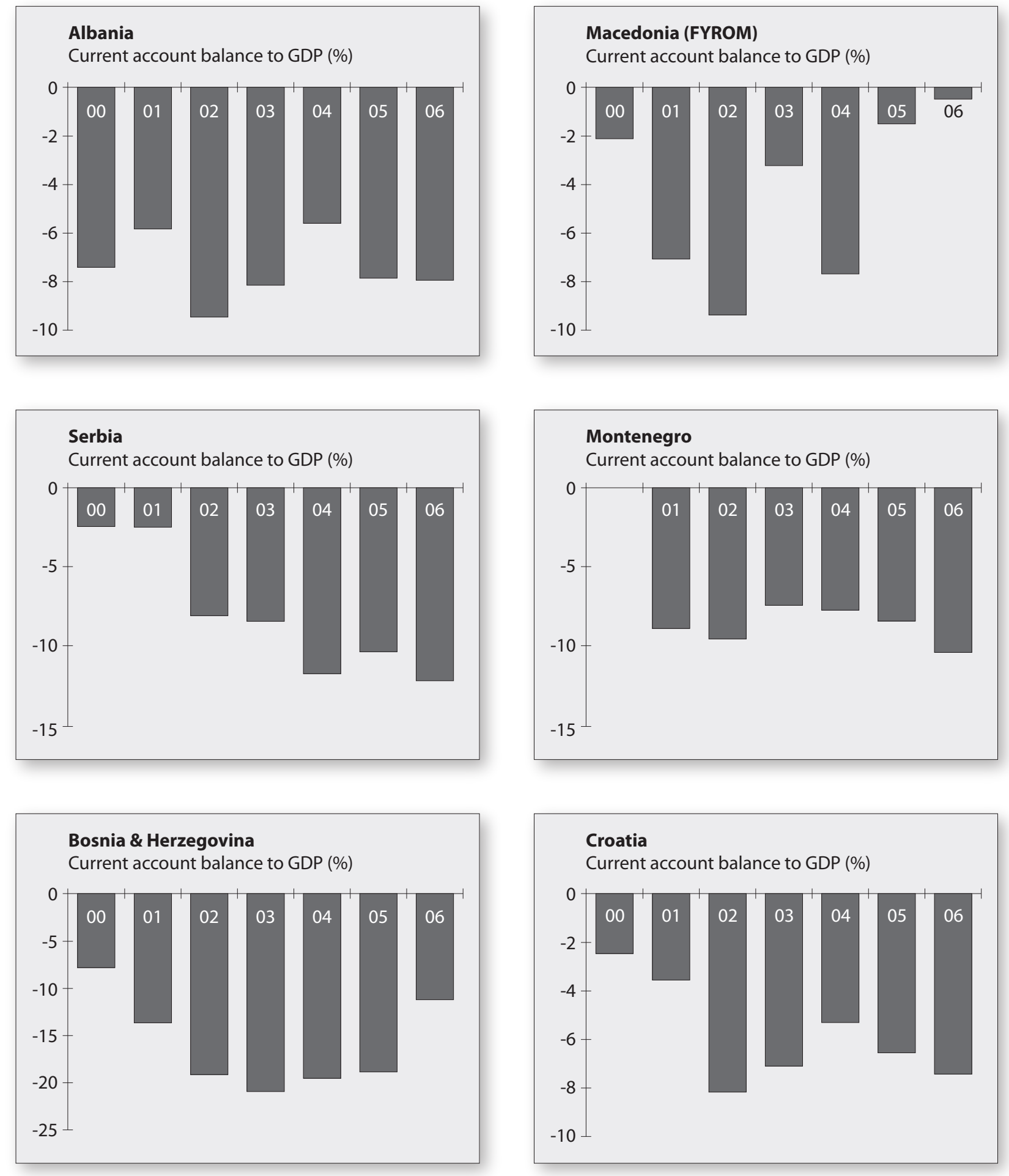

Figure 1. Current account balance to GDP (\%)

Source: World Bank "Country at a glance"(28.09.2007)

The data shows that the export inside the region goes from $7.8 \%$ (Croatia) to $41.6 \%(\mathrm{BiH})$. The largest part of exports is oriented toward EU countries.. In the countries total exports, exports within the region are about $23 \%$, while the one with EU is about $64 \%$. The main country where are directed the exports of the majority of the countries, is Serbia, to whom goes $23.1 \%$ of the Montenegro exports, $19.2 \%$ Macedonian exports, and 5.3\% Croatian exports.

The data vary from $2.20 \%$ (Croatia) to $48.94 \%$ (Montenegro). In the total imports around $11 \%$ seize the imports from region and $64 \%$ from EU countries. The mainly importing country is still Serbia. From this country come $35.1 \%$ of Montenegro, $20.0 \%$ of Bosnia-Herzegovina, $8.6 \%$ of Macedonia and $2.8 \%$ of Albania.

Concerning Albania, the data show that imports are coming mostly from Serbia 2,8\% and Macedonia 2,0\%. At the same time, Albania export in Macedonia 2,3\% and Serbia $1,9 \%$.

To show in brief the level of economic integration between different west Balkan countries, we can analyze the data from Table 5 . 
Table 3. Ratio of export with others West Balkans' Countries (2007)

\begin{tabular}{|c|c|c|c|c|c|c|c|c|}
\hline & Albania & Macedonia & Serbia & Montenegro & $\begin{array}{c}\text { Bosnia \& } \\
\text { Herzegovina }\end{array}$ & Croatia & West Balkan & European Union \\
\hline Albania & & $2.3 \%$ & $1.9 \%$ & $0.4 \%$ & $0.4 \%$ & $0.1 \%$ & $5.1 \%$ & $82.9 \%$ \\
\hline Macedonia & $2.4 \%$ & & $19.1 \%$ & $0.9 \%$ & $2.6 \%$ & $4.9 \%$ & $29.9 \%$ & $67.4 \%$ \\
\hline Serbia & $1.3 \%$ & $4.9 \%$ & & $9.6 \%$ & $11.8 \%$ & $5.9 \%$ & $33.5 \%$ & $54.5 \%$ \\
\hline Montenegro & $2.5 \%$ & $0.2 \%$ & $23.1 \%$ & & $5.7 \%$ & $2.4 \%$ & $33.9 \%$ & $63.9 \%$ \\
\hline Bosnia \& Herzegovina & $0.6 \%$ & $1.6 \%$ & $11.9 \%$ & $6.84 \%$ & & $21.8 \%$ & $41.4 \%$ & $63.0 \%$ \\
\hline Croatia & $0.3 \%$ & $0.9 \%$ & $5.3 \%$ & $1.2 \%$ & na & & $7.7 \%$ & $71.0 \%$ \\
\hline
\end{tabular}

Source: Statistics of different countries and General Custom Directory - Albania and author's own calculation.

Table 4. Ratio of import with others West Balkans' Countries (2007)

\begin{tabular}{|c|c|c|c|c|c|c|c|c|}
\hline & Albania & Macedonia & Serbia & Montenegro & $\begin{array}{c}\text { Bosnia \& } \\
\text { Herzegovina }\end{array}$ & Croatia & West Balkan & European Union \\
\hline Albania & & $2.0 \%$ & $2.8 \%$ & $0.2 \%$ & $0.3 \%$ & $1.0 \%$ & $6.2 \%$ & $62.8 \%$ \\
\hline Serbia & $0.4 \%$ & $3.5 \%$ & & $0.7 \%$ & $2.8 \%$ & $2.8 \%$ & $10.1 \%$ & $55.1 \%$ \\
\hline Montenegro & $0.6 \%$ & $1.1 \%$ & $35.1 \%$ & & $5.8 \%$ & $6.4 \%$ & $48.8 \%$ & $45.0 \%$ \\
\hline Croatia & $0.0 \%$ & $0.8 \%$ & $1.3 \%$ & $0.0 \%$ & $0.1 \%$ & & $2.2 \%$ & $65.1 \%$ \\
\hline
\end{tabular}

Source: Statistics of different countries and General Custom Directory - Albania and author's own calculation.

We can see that Montenegro (38.1\% exports and 48-9 imports), but also Bosnia \& Herzegovina (42.6 and $41 \%$ ) have the strongest regional connections. The percentage for Albania is very low, $9.9 \%$ exports and $6.8 \%$ imports. Beside Croatia, this structure is closely related to the fact that the countries of ex Yugoslavia were integrated in a single economy before the collapse of the Federation.

Total imports and exports within the region for 2007 were 4.800 million Euros. For this year, total regional exports toward EU are calculated at 13 billion Euros, while imports 26.2 billion Euros, with a coverage index of $48 \%$.

Anyway, can these data considered such to characterize a intensive cooperation between the countries in the region? Percentage after all depends from the weight of different economies, development level, competitiveness of their economies etc.

In order to get a clear picture we ca use the coefficient of trade intensity of one country within the region with other countries of the same region. This coefficient compares

Table 5. Ratio of export and import for different West Balkans' Countries within region and EU (2007)

\begin{tabular}{|l|l|l|l|l|}
\hline \multirow{2}{*}{} & \multicolumn{2}{|c|}{ West Balkan Region } & \multicolumn{2}{c|}{ European Union } \\
\cline { 2 - 5 } & Export & Import & Export & \multicolumn{1}{c|}{ Import } \\
\hline Albania & $9.9 \%$ & $6.8 \%$ & $82.9 \%$ & $62.8 \%$ \\
\hline Macedonia & $30.8 \%$ & $11.6 \%$ & $67.4 \%$ & $77.3 \%$ \\
\hline Serbia & $35.1 \%$ & $48.9 \%$ & $63.9 \%$ & $55.1 \%$ \\
\hline Montenegro & $35.1 \%$ & $48.9 \%$ & $63.9 \%$ & $45.0 \%$ \\
\hline $\begin{array}{l}\text { Bosnia \& } \\
\text { Herzegovina }\end{array}$ & $41.6 \%$ & $41.0 \%$ & $63.0 \%$ & na \\
\hline Croatia & $7.8 \%$ & $2.2 \%$ & $71.0 \%$ & $65.1 \%$ \\
\hline
\end{tabular}

Source: Statistics of different countries author's own calculations the weight of imports and exports of one country toward the countries in the region, with the weight of the entire region in international economic relations. If the index is higher than 1 , the country can be considered of higher exchange intensity with the region than with the global economy in general.

Difficulties in calculating this coefficient has constrained us to focus on calculations made some years ago for the period 1996-2004 in a study prepared by the United Nations. (Table 6)

First, for SEE it is evident that the index is higher than the unit; that shows that the intensity of the relation of the country with its region is higher than the region relations with the global economy. This coefficient for the year 2004 varies from 2.51 (Albania) to $48.94(\mathrm{BiH})$. Second, except $\mathrm{Al}$ bania, it shows that the index is much higher than SEE-7 to EU-25. Third, in general the index has decreased comparing to SEE-7, while there is a small increase toward EU-25.

If this tendency, decreasing of intensity, continued even in the following years or not, can easily be seen through an-

Table 6. Index of intensity's trade among SEE -7 and EU -25

\begin{tabular}{|l|r|r|r|r|r|r|}
\hline & \multicolumn{3}{|c|}{ SEE - 7 } & \multicolumn{3}{c|}{ EU - 25 } \\
\cline { 2 - 7 } & 1996 & 2000 & 2004 & 1996 & 2000 & 2004 \\
\hline Albania & 9.19 & 7.24 & 2.51 & 2.19 & 2.44 & 2.23 \\
\hline Macedonia & 57.51 & 64.05 & 39.76 & 1.28 & 1.23 & 1.41 \\
\hline $\begin{array}{l}\text { Serbia \& } \\
\text { Montenegro }\end{array}$ & 75.83 & 61.52 & 45.87 & 0.96 & 1.26 & 1.31 \\
\hline $\begin{array}{l}\text { Bosnia \& } \\
\text { Herzegovina }\end{array}$ & 59.98 & 55.86 & 48.49 & 1.15 & 1.25 & 1.33 \\
\hline Croatia & 30.53 & 34.73 & 31.32 & 1.74 & 1.82 & 1.59 \\
\hline
\end{tabular}

Source: V. G. Wittich "Some aspects of recent trade developments in South East Europe". 
Table 7. Ratio of export and import with West Balkans' Countries2006 - 2007 (\%)

\begin{tabular}{|l|l|l|l|l|}
\hline \multirow{2}{*}{} & \multicolumn{2}{|c|}{ Export } & \multicolumn{2}{c|}{ Import } \\
\cline { 2 - 5 } & \multicolumn{1}{|c|}{2006} & \multicolumn{1}{c|}{2007} & \multicolumn{1}{c|}{2006} & \multicolumn{1}{c|}{2007} \\
\hline Albania & $7.6 \%$ & $9.9 \%$ & $4.7 \%$ & $6.8 \%$ \\
\hline Macedonia & $32.7 \%$ & $30.8 \%$ & $10.7 \%$ & $11.6 \%$ \\
\hline Serbia & $29.8 \%$ & $35.1 \%$ & $8.1 \%$ & $10.3 \%$ \\
\hline Montenegro & $35.3 \%$ & $35.1 \%$ & $36.9 \%$ & $48.9 \%$ \\
\hline $\begin{array}{l}\text { Bosnia \& } \\
\text { Herzegovina }\end{array}$ & $34.1 \%$ & $42.2 \%$ & $23.7 \%$ & $41.1 \%$ \\
\hline Croatia & $6.5 \%$ & $7.8 \%$ & $2.0 \%$ & $2.2 \%$ \\
\hline
\end{tabular}

Source: Statistics of different countries and General Custom Directory - Albania and author's own calculations

other indicator, that of dynamics in the change of imports and exports specific weight of each country for the West Balkan region. For the latter years, data show of a relatively increase of weight of intraregional trade. So for Croatia, exports with countries in West Balkans in 2007 compared to 2006 were $7.7 \%$ versus $6.4 \%$; while imports $2.2 \%$ versus $2.0 \%$. For Serbia, exports were $35.12 \%$ (2007) versus $29,9 \%$ (2006), while imports were respectively 10.7\% (2007) versus 9.0\% (2006). For Albania in 2007 there is an increase in the weight of exports within the region by $2 \%$ compared to 2006, the same is the decrease in imports (Table 7):

\section{The dynamics and the trade relations structure of Albania with West Balkan countries}

From the aforementioned data it is evident the fact that Albania has relatively lower economic integration level in the region than the other countries. This aspect is understandable ascertainment if we consider the fact of the isolation before the ' 90 and the other fact that in the region there are that were part of one Federation (FRY), where labor social division and specialization were of a certain level.

However, even for Albania, if we consider the change in dynamics of exports and imports in the region we will see that this weight has increased. (Table 8)

The increase of the specific weight of exports and imports, although modestly, shows in fact of a higher intensity of the Albania relations with the other countries in the region. Which are the main factors for this increase? I think that two main factors can be taken into consideration: (i) signing of Free Trade Agreement regional countries (ii) the increase of competitiveness of the region economies in the global economy.
We can see that the biggest increase was by the specific weight in 2006 and 2007, years belonging to the end of FTA signing with the regional countries. Anyway, the period that these data belong is relatively short and the change of tendency in the upcoming years will give as a full view about the determinate factors of the change of this structure. On the other side if we analyze the structure of Albania' imports and exports with the regional countries we can see that the main products to be imported and exported continue to be different raw materials. Of course, this characteristic reflects another important aspect of the nature of Albanian integration in the regional economy.

\section{Conclusion}

- The regional integration of the West Balkan countries represents an important aspect of European integration for countries in this region, it can be considered as a preparatory phase for their integration into EU. A very important aspect for the integration is economic collaboration with the region countries

- West Balkan countries have had a relatively fast progress toward their regional integration politics in the economic field. The process started in 1999 with the Stability Pact that was concretized lately with the CEFTA -2006 agreement.

- Macroeconomic stability of the west Balkan countries and the opening of their economies is followed by deficits of current accounts and trade balances. The positive correlation among the economy opening scale of special countries and foreign direct investment if these countries, is not something casual. This correlation shows the fact that trade development is the result of the increase in economies' competitiveness for countries in the region, which on the other side depends largely on foreign investments.

- The trade intensity level among region countries is relatively high, especially among Ex Yugoslavia Federation. Data shows that this intensity, despite with its decrease for the period 1996 - 2004, has increase for the period 2006 - 2007. The export and import part of the different countries with other region countries show an increasing tendency.

- Albania, compared to other west Balkan countries, shows a low level of economic cooperation, what is unexplainable with the country isolation before the '9o. How-

Table 8. Change of ratio of Albanian's export and import with other West Balkan Countries (\%)

\begin{tabular}{|c|c|c|c|c|c|c|c|c|}
\hline & \multicolumn{4}{|c|}{ Export } & \multicolumn{4}{|c|}{ Import } \\
\hline & 2004 & 2005 & 2006 & 2007 & 2004 & 2005 & 2006 & 2007 \\
\hline Macedonia & $1.3 \%$ & $1.6 \%$ & $1.6 \%$ & $2.3 \%$ & $1.0 \%$ & $1.2 \%$ & $1.6 \%$ & $1.9 \%$ \\
\hline Serbia \& Montenegro & $0.4 \%$ & $0.8 \%$ & $1.4 \%$ & $1.9 \%$ & $0.6 \%$ & $0.6 \%$ & $0.9 \%$ & $3.0 \%$ \\
\hline Montenegro & - & - & - & $0.4 \%$ & - & - & - & $0.1 \%$ \\
\hline Bosnia \& Herzegovina & $0.1 \%$ & $0.2 \%$ & $0.5 \%$ & $0.4 \%$ & $0.1 \%$ & $0.1 \%$ & $0.3 \%$ & $0.3 \%$ \\
\hline Croatia & $0.1 \%$ & $0.0 \%$ & $0.3 \%$ & $0.1 \%$ & $1.3 \%$ & $1.2 \%$ & $1.4 \%$ & $1.0 \%$ \\
\hline Total & $1.9 \%$ & $2.6 \%$ & $3.8 \%$ & $5.1 \%$ & $3.0 \%$ & $3.1 \%$ & $4.2 \%$ & $6.3 \%$ \\
\hline
\end{tabular}

Source: Statistics of different countries and General Custom Directory - Albania and author's own calculation. 
ever, the characteristic is that even for this country the tendency of increase of specific weight of the trade with other countries in the region.

\section{References}

ACIT, 2007. Albania 2007 - Trade Raport

Central Bureau of Statistics Croatia, 2008. Mjesečno Statusticko Izvješće 2007, Number 12. http://www.dzs.hr

Federal Office of Statistics of Bosnia and Herzegovina. http://www.fzs.ba/

Institute of Statistics Albania -INSTAT. http://www.instat. gov.al/

Stability Pact, 2004. Working Group on Trade Liberalization \& Facilitation: Strategy and Action Plan for 2005, Stability Pact for South Eastern Europe, Working Table II: Economy, Trade Working Group.

Stability Pact, 2001. Main features and full text of the Memorandum of Understanding on Trade Liberalization and Facilitation, Regional table Document, Brussels, 27 June 2001.
State Statistical Office FYROM, 2008. Stokovna Razmena - External Trade (08.02.2008). http://www.statserb.sr.gov. yu

Statistical Office of Montenegro, 2008. Trgovinska razmjena Crne Gore za januar -decembar 2007. godine. www. monstat.cg.yu

Statistical Office of the Republic of Serbia, 2007. Exports and Imports of Serbia, December 2007. http://www.statserb.sr.gov.yu

UNECE Countries in Figures, 2007. http://www.unece.org/ stats/profiles2007/Welcome.html Uvalic, M. 2005. Trade Liberalization in Southeast Europe - Recent Trends and Some Policy Implications. University of Perugia.

World Bank, 2008. Country at a glance (28.09.2007).

World Bank, 2008. World Development Indicators (WDI), April 2008.

World Trade Organization, 2005. Country Report. http:// www.wto.org

Wittich, V.G. 2005. Some aspects of recent trade developments in South -East Europe. UNECE, Discussion Paper Series, No.6, December 2005. 
